\title{
University Curriculum-Recent Philosophical Reflections and Practical Implementations
}

\author{
Juha Himanka \\ Faculty of Arts, University of Helsinki, Helsinki, Finland \\ Email: juhathimanka@gmail.com
}

Received October 29 th $^{\text {th }}$ 2013; revised November 29 ${ }^{\text {th }}$, 2013; accepted December $6^{\text {th }}, 2013$

\begin{abstract}
Copyright (c) 2013 Juha Himanka. This is an open access article distributed under the Creative Commons Attribution License, which permits unrestricted use, distribution, and reproduction in any medium, provided the original work is properly cited. In accordance of the Creative Commons Attribution License all Copyrights (c) 2013 are reserved for SCIRP and the owner of the intellectual property Juha Himanka. All Copyright @ 2013 are guarded by law and by SCIRP as a guardian.
\end{abstract}

\begin{abstract}
Philosophers Martha Nussbaum and Alasdair MacIntyre have recently made a discussion on the university curriculum. MacIntyre formulated the problem in the following way: "a surprising number of the major disorders of the latter part of the twentieth century and the first decade of the twenty-first century have been brought about by some of the most distinguished graduates of some of the most distinguished universities in the world". The problem is that these universities give inadequate general education. The situation even seems to be getting worse as Nussbaum is concerned about the direction that curriculum design has recently taken in some parts of the world. In this article, however, I will cite a few examples of university curriculum design that give some promising solutions to the problems posed by philosophers. Especially the new Common Core Curriculum of the University of Hong Kong offers possibilities that might lead the way to a new and more responsible manner of designing a university curriculum.
\end{abstract}

Keywords: University; Curriculum; Education; Globalization

\section{Introduction}

Two eminent philosophers, Alasdair MacIntyre and Martha Nussbaum, have recently published essays in which they express their concern over university education (MacIntyre, 2009; Nussbaum, 2010). Both philosophers are scholars of antiquity, and the roots of their views are to be found in the ideas of education already presented by Plato and Aristotle. I will visit these age-old views on higher education, but my main aim is to look into some fresh attempts at building a responsible and up-todate university curriculum. I will finish by focusing on how the ancient ideas on education in their new formulations go together with new versions of university curricula.

\section{Alasdair Macintyre}

Alasdair MacIntyre held the John Henry Newman Lecture in Blackfriars, Cambridge, on June 9, 2009. The lecture was entitled "The Very Idea of a University: Aristotle, Newman and Us" and it was published in British Journal of Education Studies in the same year. MacIntyre argues in his paper against the more and more popular points of view that regard the discussion on the idea of university as an outdated topic. Proponents of these types of analyses think that the field of higher education is so diverse nowadays that no general doctrine of universities is any longer possible. MacIntyre disagrees and states that the views presented by John Henry Newman in his The Idea of University $(1852,1858)$ are still relevant and worth careful consideration. According to MacIntyre's view, if we cease to ask what the idea of university means, we will also have stopped asking what an educated mind is.

MacIntyre's philosophical background is Aristotelian and it is therefore no wonder that he quoted the following famous passage from the above-mentioned book by Newman:

"While we are men, we cannot help, to a great extent, being Aristotelians, for the great Master does but analyse the thoughts, feelings, views, and opinions of human kind. He has told us the meaning of our own words and ideas, before we were born. In many subject-matters, to think correctly, is to think like Aristotle; and we are his disciples whether we will or no though we may not know it." (Newman, 1907, 1852, 1858/73: pp. 109-110; cf. MacIntyre, 2009)

Does this mean that MacIntyre thinks that we in the $21^{\text {st }}$ century are still Aristotelians in relation to the university, but are simply not aware of it?

During the formatting years of the universities in the Middle Ages, the works of Aristotle were the main syllabus in teaching. The reading list for the licentia docendi of a magister artium in 1255 at the University of Paris, for example, included 25 books of which 19 were from the Aristotelian corpus (Pedersen, 1997: pp. 278-279). Furthermore, we can find some signs of Aristotelian thought in our teaching arrangements even today. Aristotle, for example, thought that although sight is our most appreciated sense, we actually learn better by hearing. For centuries professors taught by reading books out loud while students listened. This was called lecturing, and we can still sometimes see that this background influences our lectures even today. MacIntyre is, however, not trying to return to the roots of traditional ways of teaching here. Instead, he seems to think that there is another 
aspect of the Aristotelian doctrine of learning that is still up to date.

According to MacIntyre, an educated mind should know what he or she is doing. Although MacIntyre does not point this out, the view is to be found in Aristotle's Metaphysics. In the first section of the first book of Metaphysics, Aristotle considers what it means to know better (mallon eidenai). It is customary to find four criteria for knowing better in the text (Heidegger, 2005, §10b): 1) knowing the reasons or causes; 2) knowing does not aim at immediate utility; 3) knowing goes beyond common perception and 4) the one who knows something is also able to teach it. With the hint given by MacIntyre we can, however, also point out a fifth criterion.

Right after Aristotle has mentioned the possibility of knowing better, he presents the difference between artisans and master craftsmen. Here the master craftsmen know better:

"We consider that the master craftsmen in every profession are more estimable and know more and are wiser than the artisans, because they know the reasons of the things which are done; but we think that the artisans, like certain inanimate objects, do things, but without knowing what they are doing. (9801a-b, my italics)

A sloppy reader might only see here the aspects of connecting knowing better with knowing reasons, but actually the passage also connects knowing better with knowing what one is doing. What does it mean, then, to know what one is doing?

It is actually not that easy to know what we are doing in a given social setting. MacIntyre gives an example of how one might answer the question, "What are you doing?": "Solving an equation; predicting next week's stock prices; pleasing my employer; working late in the office; absenting myself from dinner with my family; alienating my oldest child” (p. 359). In any given situation the answer to the question, "What are you doing?" is more complicated than one might at first think. One must be educated even to understand the scope of the question, and to answer the question requires quite an extensive education.

MacIntyre presents his critique against our present university curriculum. He points out that some important questions go unasked in the contemporary curriculum, such as the question of human beings and their self-reflection in general (cf. 355). The critique then proceeds onto a more concrete level. MacIntyre asserts that "a surprising number of the major disorders of the latter part of the twentieth century and the first decade of the twenty-first century have been brought about by some of the most distinguished graduates of some of the most distinguished universities in the world." This is the result of "an inadequate general education ... that has made it possible for those graduates to act decisively and deliberately without knowing what they are doing." (p. 361). MacIntyre gives three examples of such disasters: the Vietnam War, the policies of the United States towards Iran and the present world economic crisis.

As a forerunner of the last-mentioned disaster MacIntyre points out the case of Long-Term Capital Investment. The collapse of this hedge fund in 1997 was so massive that for a short time it threatened the entire financial system (p. 361). The executives of the fund knew what they were doing as far as mathematics and economic theory were concerned. As the collapse demonstrated, what they did not in fact know was what they were doing in the actual world with people, because they lacked "historical knowledge of two kinds of contingency: knowledge in depth of the histories of risk-taking firms and of the vicissitudes encountered in those histories and knowledge of the politics of the different cultures within which markets operate” (p. 361).

To sum up, MacIntyre thinks we should still ask what an educated mind is. His proposal for an answer is: an educated mind knows what she or he is doing. In addition, in a democratic society there is one particularly important act, voting, during which we should know what we are doing. It follows that we should be able to recognize the people who know what they are doing.

\section{Martha Nussbaum}

Another modern Aristotelian philosopher, Martha Nussbaum, has also dealt with these questions in her book Not for Profit: Why Democracy Needs the Humanities (2010). According to Nussbaum we should still teach in the Socratic manner and stimulate students to think and argue for themselves. Nussbaum also stresses that our problems today are global in their scope. It follows that we should develop strategies to make students global citizens.

In comparison with MacIntyre, Nussbaum is more in debt to Plato than to Aristotle. She writes "the dialogues of Plato are second to none for their capacity to inspire searching, active thinking, with the life and example of Socrates up front to inspire” (p. 55). As an example Nussbaum points out the famous section where Socrates teaches the slave boy to double the area of a square in Plato's dialogue Meno. Socrates there asks dozens of questions and draws figures on the sand until the boy realizes the answer himself. The point is that the boy has to figure out the answer himself without Socrates telling it to him. As the student was only a slave and did better than many leading figures of Athens in discussion with Socrates, this also demonstrates how Socratic critical inquiry is utterly non-authoritarian: "the status of the speaker does not count, only the nature of the argument” (pp. 50-51).

This Platonic or Socratic point of view that the student himself or herself should be an agent in learning holds a strong position in Western views on education. The proponents of this view include, for example, René Descartes, François de Fénelon, Jean Jacques Rousseau, Friedrich Schelling, Wilhelm von Humboldt, Victor Cousin and J. V. Snellman (Himanka, 2012). Nussbaum, however, points out that a similar Socratic view on education can be found even outside Europe from very early on already.

When the student is not understood as a passive listener but as an active self in teaching, the student will gradually learn what it means to be a responsible subject in society. He or she will develop a capacity to empathy, understand others as subjects and learn to understand what kind of responsibilities we have in different groups and societies. In this way the student will learn how to be a citizen in a democratic society and a citizen of the world.

Nussbaum has her own opinion on how this kind of education should be arranged at the university level. She argues strongly for the liberal arts model of curriculum that is used in many major universities in the United States. Although the model has turned out to be very successful, it is no longer seen as an example to be followed. It is this development that worries Nussbaum.

To sum up: According to Nussbaum, the university curriculum should still include sections that follow the liberal arts 
model and give all students a wide cultural education. The Socratic model where the student is an active participant and where the argumentation rules over the authority of the speaker is the best way to educate people in democratic societies.

There are, however, counter examples to the development described by Nussbaum. The University of Winchester (UK), for example, has started a programme called Modern Liberal Arts. The starting point there is that the important questions we humans need to ask cannot be contained within a single academic discipline. I visited the programme a few years ago and was impressed how the students were really able to handle the big questions from the perspective of their own situations. In order for this to happen, students, however, need good supervision, and that presupposes capable professors. Perhaps we could find other examples of encouraging trends within higher education? Let us therefore take a look at what else is happening in university curriculum design. I will take two examples, Stanford and Hong Kong.

\section{Stanford University}

In the late 1980's, there was a big debate over the university curriculum in Stanford University. During the first few months of 1988, the University, then in the midst of its centennial celebration, found itself constantly in the national news. The debate dealt with the question whether or not to retain a list of fifteen mandatory works in the first-year course of Western culture. The problem was that these courses said nothing or very little about the non-European cultures. On one side of the debate, Stanford Black Student Union called the course "racist" and on the other side, a local newspaper reported the Senate's abandonment of the list with the headline "Stanford Puts an End to Western Civilization.” I will not focus on the debate here, but will instead turn to a recent report by Study of Undergraduate Education at Stanford (SUES) (Lindenberger, 1990).

The SUES report tells us that "the curricular wars" of the 1980s had their impact. Now the goals of education are not defined by their content. Instead, the aims of education are described as capacities that students will have when they graduate. How does the report itself, then, describe the aims of Stanford education?

The part of the report that deals with the aims of Stanford education starts by pointing out that "Stanford grounding grant states the university's 'object' succinctly: 'to qualify its students for personal success, and direct usefulness in life."' Here we are immediately in conflict with the philosophical views presented above. In what follows, however, the report turns to a direction that is much more in agreement with the philosophers.

The report sets three major aims for Stanford education. The first one stresses that the graduates should be able to communicate effectively. At the end of the section, the report affirms that the aim is not only a student's personal success: "In a world rife with misunderstanding and riven by all manner of political and sectarian dispute, nothing is more important to responsible citizenship than the capacity to communicate" (p. 12).

The second aim of Stanford education consists of the capacities students should acquire during their years at Stanford. The list includes critical thinking, aesthetic and interpretative judgment, formal and quantitative reasoning skills and an ability to think historically. The list does not include the social skills which Nussbaum valued so highly. However, I will discuss these in conjunction with the third aim of Stanford education.
Before moving on to the third aim, the report points out that the students having acquired the above-mentioned skills are well on their way to personal success. The report is not content with this, however: "Yet if the history of the modern world teaches us anything, it is that knowledgeable and skillful people are capable of doing great harm as well as great good.” (p. 12) This we saw with MacIntyre's examples such as the Vietnam War. Does the report, then, follow the lines set by philosophers with its third aim?

The third aim is the most important one from our perspective. The report states:

"If our graduates are to assume the responsibilities of local, national, and global citizenship, they need not only deep knowledge and well-honed skills but also a wider set of characteristics and competencies: a sense of personal and social responsibility; ethical and moral reasoning skills; an appreciation of cultural difference, as well as of human communality; the ability to work collaboratively in diverse teams; tolerance, generosity, and a broad capacity to empathy.” (p. 12)

The third aim underlines responsibility, empathy and communality and is thus well in line with the aims set by our philosophers.

\section{The University of Hong Kong}

My second example of a university curriculum is the new Common Core Curriculum of the University of Hong Kong. The university had prepared this four-year undergraduate curriculum for five years before it was launched in full in 2012. The curriculum is called common because it deals with matters which are common to all human societies and are issues of fundamental importance to all humankind. It is called core because after taking these courses students will hold the core values of a democratic society. The curriculum is designed to provide a fundamental common learning experience for all University of Hong Kong undergraduate students. It seems that MacIntyre's questions on human beings and their self reflection are presented in a contemporary curriculum after all.

What will the student study within the Common Core Curriculum? The introduction in the Student's Handbook informs us that the curriculum is "designed to help students see the interconnectedness and interdependent nature of human existence through exploring common human experiences”. The curriculum does not only change the emphasis from content to capacities but goes on to focus on experiences common to all human beings. The curriculum is highly ambitious as it aims to explore fundamental human experiences instead of just increasing the student's knowledge of these things. How is this to be done? Let us take a glance at the goals.

The Common Core Curriculum sets four goals. The fourth on the list comes close to the second aim of Stanford education and deals with the intellectual skills that will be further enhanced in disciplinary studies. We are here mainly interested in the first three goals.

The first goal aims to enable students to develop a broader perspective and critical understanding of the complexities they confront in their everyday lives. The second aims to cultivate students to appreciate their own and other cultures. The third aims to enable students to see themselves as citizens and responsible individuals of global and local communities. All these certainly point to the same direction as the curricula outlined by Nussbaum and MacIntyre. 
The Handbook sets further goals in each discipline. Within the humanities, for example, the first objective is to enable students "to gain an understanding of the distinctive qualities and experiences of being human" (p. 13). The Handbook then gives seven other objectives and turns to key themes. The section of key themes first lists traditional fields of study in the humanities: language, history, literature, visual and performing arts, and philosophy. The curriculum however sets up a different, interdisciplinary list of key themes: The Creative Arts; Historical Awareness: Past and Present; Language, Communication and Society; Mind-Body-Spirit and Ethics and Society.

Students who have reached these goals will have a better understanding of what they are doing and will be more responsible global citizens. How are the students, then, to reach these goals?

We cannot go into details of the 180 pages long Common Core Curriculum Student Handbook 2013-2014 here, but we can take a quick look at what kind of programmes and courses the curriculum offers. There are 157 courses to choose from. I will pick up a few examples. The courses are divided into four areas of inquiry: 1) Science and Technological Literacy, 2) Humanities, 3) Global Issues and 4) China: Culture, State and Society. Let us select one course of each of these areas: Our Place in the Universe (Science), The Last Dance: Understanding Death and Dying (Humanities); Understanding Financial Crisis and The Political Economy of Growth and Poverty in the World (Global Issues) and People, Propaganda and Profit: Understanding Media in China (China).

At first glance, the programme and goals of the Common Core Curriculum seem very ambitious, almost too ambitious to be achieved. However, when one studies the details and sees how carefully the whole curriculum is planned, its goals appear more and more realistic.

\section{Conclusion}

I started with a concerned philosophical comment on setting aims in higher education. MacIntyre's example of Long-Term Capital Management is a good illustration of the problem. The main idea of this hedge fund was to use the latest scientific model and hire highly educated academic staff. They even had two Nobel prize winners in their team. The fund failed miserably, and analyses afterwards had shown quite convincingly that the main problem was the too narrow education of those who were in charge (Kolman, 1999; Lewis, 1999; Lowenstein, 2000). If the executives of the fund had graduated from the Common Core Curriculum, the catastrophe would probably never have happened. They would have taken the course on Understanding Financial Crises and seen beforehand what might happen.

Philosophers suggest that we should take care of a wide enough curriculum at the university level. Our graduates should have enough wisdom to know what they are doing and the kind of education in which they understand themselves as responsible citizens. The aims of Stanford Education take us a long way in that direction, but if the Common Core Curriculum really works in practice, it could take us all the way. That remains to be seen.

According to the old Platonic educational ideal, we should align our education with the ideal society. It follows that if we want our society to be a well functioning democracy, we should educate our students to be good and responsible citizens in that type of society. And if we want to have a well functioning society that covers the whole humanity on Earth, we should teach our students to be global citizens. But what are we to teach to our students in order to reach these goals? How are we to evaluate whether students have developed "a sense of personal and social responsibility" and indeed have a "broad capacity to empathy" as the Aims of Stanford Education states?

The Common Core Curriculum gives some answers to these extremely difficult questions. The course titled The Last Dance: Understanding Death and Dying, for example, states that on completing the course a student will be able to "appraise the impact of death and loss in societal level” (p. 86). It would be a good thing to be able to do this if one is responsible for decisions that might cause deaths. And perhaps those who are responsible for current economic crises would have made different decisions if they had taken a course on Economic Globalization. In other words, if they had known what they were doing, they would have realized that their actions could cause 50 million people to lose their jobs world-wide (ILO, 2010). In addition, they should have been responsible enough to see that these risks would count more than their own personal success. Furthermore, the organization that chooses the executives should value people who know what they are doing. In the present situation that seems to be a utopian scenario (cf. Lewis, 1989). But within democratic control in a society where citizens can tell the difference between those who know what they are doing and those who do not, we would enjoy the benefits of good education. The Common Core Curriculum does offer some elements that seem to point to that direction, where the results of good education are not only successful graduates, but also a better society or even a better world.

\section{REFERENCES}

Aristotle. http://www.perseus.tufts.edu/hopper/

Himanka (2012). The University as a community of selves, Johan Vilhelm Snellman's “On Academic Studies”. Higher Education, 64, 517-528. http://dx.doi.org/10.1007/s10734-012-9508-5

Heidegger, M. (2005). Phänomenologische interpretationen ausgewählter abhandlungen des aristoteles zur ontologie und logik. Frankfulrt am Main: Vittorio Klostermann.

University of Hong Kong (2013). Common Core Curriculum, Student Handbook 2013-2014.

http://commoncore.hku.hk/files/cc13-lowres.pdf

ILO (2010). Global employment trends.

http://www.ilo.org/wcmsp5/groups/public/---ed_emp/---emp_elm/---t rends/documents/publication/wcms_120471.pdf

Kolman, J. (1999).

http://www.derivativesstrategy.com/magazine/archive/1999/0499fea 1.asp

Lewis, M. (1989). Liar's poker, rising through the wreckage on Wall Street. New York: W. W. Norton \& Company.

Lewis, M. (1999). How the eggheads cracked. New York Times, 24 January1999.

Lindenberger, H. (1990). On the sacrality of reading lists: The western culture debate at Stanford University. http://www.pbs.org/shattering/lindenberger.html

Lowenstein, R. (2000). When genius failed, the rise and fall of longterm capital management. New York: Random House.

MacIntyre, A. (2009). The very idea of a university: Aristotle, Newman, and Us. British Journal of Educational Studies, 4, 347-362. http://dx.doi.org/10.1111/j.1467-8527.2009.00443.x

Newman, J. H. (1852). The idea of university. London: Longmans, Green, and Co.

Nussbaum, M. C., (2010). Nor for profit, why democracy needs the 


\section{J. HIMANKA}

humanities. Princeton, NY: Princeton University Press.

Pedersen, O. (1997). The first universities: Studium generale and the origins of university. Cambridge: Cambridge University Press.
Plato. http://www.perseus.tufts.edu/hopper/

SUES report (2012). The study of undergraduate education at Stanford University. http://www.stanford.edu/dept/undergrad/sues/report.html 